\title{
Penggunaan Model Pembelajaran Kooperatif Tipe Struktural Think Pair Share pada Materi Pembentukan Bayangan Benda pada Lensa Cembung
}

\author{
Audi Wibowo
}

\author{
Madrasah Tsanawiyah Negeri 9 Ngawi \\ Jl.Sultan Agung, Kec. Jogorogo, Kab. Ngawi, Jawa Timur 63262. \\ *Email: audiwibowo231273@gmail.com
}

\begin{abstract}
Abstrak
Tujuan penelitian ini yaitu untuk mendeskripsikan peningkatkan aktivitas dan prestasi belajar siswa pada materi pembentukan bayangan benda pada lensa cembung pada mata pelajaran IPA Terpadu setelah diterapkan model pembelajaran kooperatif metode struktural think pair share. Penelitian ini menggunakan rancangan penelitian tindakan kelas (PTK). Subyek penelelitian ini adalah siswa Kelas VIII D MTsN 9 Ngawi sebanyak 32 siswa. Secara garis besar terdapat 4 (empat) tahapan yang akan dilaksanakan pada penelitian tindakan kelas ini, yaitu meliputi: tahap (1) perencanaan (planning), (2) pelaksanaan (acting), (3) pengamatan (observating), dan (4) refleksi (reflecting). Instrumen yang digunakan dalam penelitian ini yaitu lembar observasi aktivitas siswa dan tes tertulis. Data penelitian dianalisis menggunakan rumus persentase keaktivan siswa dan persentase ketuntasan belajar siswa. Hasil penelitian menunjukkan peningkatan aktivitas dan hasil belajar siswa terlihat pada kenaikan persentase ketuntasan belajar siswa dari siklus I sebesar 60,61\% meningkat pada siklus II menjasi sebesar $81,82 \%$. Peningkatan prestasi belajar siswa juga terlihat pada nilai rata-rata hasil belajar siswa dari sebesar 66,00 pada siklus I meningkat menjadi 70,00 pada siklus II. Kesimpulan dari penelitian ini adalah penerapan model pembelajaran kooperatif metode struktural think pair share dapat meningkatkan pemahaman siswa Kelas VIII D MTsN 9 Ngawi pada mata pelajaran IPA Terpadu khususnya materi tentang pembentukan bayangan benda pada lensa cembung yang ditandai dengan peningkatan hasil belajar siswa.
\end{abstract}

Kata kunci: aktivitas siswa, hasil belajar, kooperatif, struktural think pair share.

\begin{abstract}
The purpose of this study is to describe the results of improving student activity and achievement in the material for the formation of object images on convex lenses in Integrated Science subjects after the cooperative learning model of the think pair share structural method is applied. This study uses a classroom action research (CAR) design. The subjects of this research were 32 students of Class VIII D MTsN 9 Ngawi. Broadly speaking, there are 4 (four) stages to be carried out in this classroom action research, which include: (1) planning (planning), (2) implementing (acting), (3) observing (observating), and (4) reflection (reflecting). 2) The instruments used in this study were student activity observation sheets and written tests. The research data were analyzed using the formula for the percentage of student activity and the percentage of student learning completeness. The results showed an increase in student learning outcomes seen in the increase in the percentage of students' learning mastery from the first cycle of $60,61 \%$ increasing in the second cycle to $81,82 \%$. The increase in student achievement is also seen in the average value of student learning outcomes from 66.00 in the first cycle to 70.00 in the second cycle. The conclusion of this study is that the application of the cooperative learning model of the think pair share structural method can improve students' understanding of Class VIII D MTsN 9 Ngawi in Integrated Science subjects, especially the material on the formation of object images on a convex lens which is characterized by an increase in student learning outcomes.
\end{abstract}

Keywords: learning outcomes, cooperative, structural think pair share, student activity.

\section{PENDAHULUAN}

Salah satu mata pelajaran pada tingkat sekolah menengah yang perlu ditingkatkan kualitasnya adalah IPA Terpadu karena merupakan kumpulan ilmu pengetahuan yang terorganisir secara teratur mengenai gejalagejala alam. Mata pelajaran IPA Terpadu dalam pembelajarannya melalui proses yang pada hakikatnya merupakan suatu cara untuk memecahkan masalah dengan prosedur tertentu mengenai gejala-gejala alam dalam rangka memahami gejala alam ini. Sesuai dengan hakikat pendidikan IPA Terpadu, tujuan 


\section{JPSP: Jurnal Penelitian Sains dan Pendidikan}

https://e-journal.iain-palangkaraya.ac.id/index.php/mipa/

pendidikan IPA Terpadu tidaklah hanya sekedar agar siswa dapat memiliki pengetahuan tentang gejala-gejala alam saja melainkan juga melalui pendidikan IPA Terpadu diharapkan para siswa memiliki kemampuan untuk memecahkan masalah mengenai alam sekitar (Trianto, 2013).

Sebagai upaya untuk mencapai tujuan pendidikan agar mendapatkan hasil belajar yang optimal, tidaklah cukup bila dalam proses pembelajaran IPA Terpadu menggunakan salah satu pendekatan saja. Oleh karena itu, dalam kurikulum MTs yang baru menekankan pengembangan dan penggunaan metode pembelajaran yang lebih inovatif agar dapat meningkatkan pemahaman siswa dan meningkatkan keaktifan siswa dalam proses pembelajaran. Guru MTs dalam proses pendidikan harus dapat menguasai dan menyampaikan materi pelajaran dengan baik agar siswa dapat mencapai pemahaman dan prestasi belajar yang baik. Materi pelajaran di MTs merupakan landasan yang harus ditanamkan dengan baik dalam diri siswa untuk bekal pendidikan selanjutannya.

Sebagai guru yang profesional, selain mampu menguasai materi yang akan diajarkan kepada para siswa, guru juga harus mampu menstranfer materi tersebut dengan baik sehingga hasil belajar siswa dapat optimal. Di sinilah diperlukan ketrampilan guru untuk memilih metode atau media yang tepat. Untuk mencapai pemahaman belajar siswa akan materi yang disampaikan guru harus jeli dalam memilih metode ataupun media yang sesuai dengan kemampuan dan kondisi siswa.
Berdasarkan hasil wawancara dengan siswa, mata pelajaran IPA Terpadu Kelas VIII MTs khususnya materi pembentukan bayangan benda pada lensa cembung, bagi siswa merupakan materi yang cukup membingungkan dan perlu suatu pengajaran yang ekstra. Terkadang guru hanya menerapkan penyampaian materi pelajaran IPA Terpadu tersebut hanya melalui metode ceramah dan hanya menggunakan media buku teks saja, sehingga siswa menjadi lebih sulit memahami materi tersebut dan dengan pemahaman yang rendah otomatis akan menurunkan prestasi belajar dari siswa.

Berdasarkan hasil wawancara dengan guru Kelas VIII D MTsN 9 Ngawi, diperoleh penjelasan bahwa siswa banyak yang kurang paham dan kurang tertarik mengenai materi pembentukan bayangan benda pada lensa cembung. Berdasarkan wawancara penulis dengan para siswa, diketahui bahwa mereka kurang minat dalam mempelajari materi tersebut dan mereka sering salah membedakan pembentukan bayangan benda pada lensa cembung yang satu dengan yang lainnya. Hal ini juga berdampak pada hasil prestasi hasil belajar yang dicapai oleh siswa. Ketuntasan belajar siswa belum mencapai target yang diharapkan pada saat ulangan. Berdasarkan nilai ulangan siswa bahwa dari 33 siswa hanya 10 anak (30\%) yang mendapatkan nilai diatas 70, yang lainnya yaitu 23 anak (70\%) nilainya dibawah 75 , sedangkan nilai rata-rata kelas masih rendah yaitu sebesar 60,00.

Hal ini disebabkan karena guru dalam mengajar hanya menggunakan menggunakan metode ceramah dan hanya menggunakan 


\section{JPSP: Jurnal Penelitian Sains dan Pendidikan}

https://e-journal.iain-palangkaraya.ac.id/index.php/mipa/

media buku teks saja dalam menyampaikan pelajaran. Sehingga siswa selain kurang tertarik akan materi pelajaran IPA Terpadu yang disampaikan oleh guru. Siswa juga menjadi kurang tertarik dan masih kesulitan akan materi pelajaran tersebut. Untuk menanggulangi ketidaktertarikan dan ketidakpahaman siswa akan mata pelajaran IPA Terpadu pada materi pembentukan bayangan benda pada lensa cembung tersebut. Untuk itu seharusnya guru membuat inovasi pembelajaran serta mengubah strategi pembelajaran supaya siswa lebih tertarik dan lebih paham dengan pembelajaran IPA Terpadu. Berdasarkan hasil observasi tersebut, maka diperlukan suatu penerapan model dan metode pembelajaran yang dapat meningkatkan ketertarikan siswa pada materi lensa cembung sehingga dapat meningkatkan pemahaman siswa pada materi tersebut yang berdampak pada peningkatan hasil belajar siswa.

Model pembelajaran kooperatif metode struktural think pair share menekankan pada strukur-struktur khusus yang dirancang untuk mempengaruhi pola-pola interaksi siswa (Yuwono, 2016). Berbagai struktur tersebut dikembangkan dengan maksud agar menjadi alternatif dari berbagai struktur kelas yang lebih tradisional, seperti metode resitasi, yang ditandai dengan pengajuan pertanyaan oleh guru kepada seluruh siswa dalam kelas dan para siswa memberikan jawaban setelah lebih dahulu mengankat tangan dan ditunjuk oleh guru. Struktur-struktur tersebut menghendaki agar para siswa bekerja sama saling bergantung pada kelompok-kelompok kecil secara kooperatif. Ada struktur yang memiliki tujuan umum (goal) untuk meningkatkan penguasaan isi akademik dan ada pula struktur yang tujuannya untuk mengajarkan keterampilan sosial (Fariska, 2013).

Melalui model pembelajaran kooperatif metode struktural think pair share diharapkan akan membantu siswa lebih akrab dengan temannya sehingga memudahkan untuk berdiskusi dan bertukar pendapat. Model pembelajaan kooperatif menciptakan interaksi yang saling asah, asih, dan asuh sehingga tercipta masyarakat belajar, siswa tidak hanya belajar dari guru, tetapi juga sesama siswa. Model pemebelajaran kooperatif tipe struktural think pair share menekankan pada aktifitas belajar siswa sehingga mengajak siswa untuk lebih aktif dan kreatif. Menurut penelitian yang dikemukakan oleh Irwansyah (2016) bahwa keterlibatan langsung (keaktifan) pebelajar (siswa) dalam mendapatkan pengalamanpengalaman belajar sangat berpengaruh terhadap hasil belajar dan perubahan tingkah lakunya. Oleh sebab itu metode struktural think pair share ini sangat sesuai untuk meningkatkan pemahaman siswa terutama pada mata pelajaran IPA Terpadu yang banyak terdapat eksperimen (Budiati, 2018).

Berdasarkan latar belakang masalah di atas maka penulis merasa perlu untuk melakukan penelitian tentang penggunaan model pembelajaran kooperatif tipe struktural think pair share pada materi pembentukan bayangan benda pada lensa cembung.

\section{METODE PENELITIAN}

Jenis penelitian ini adalah Penelitian Tindakan Kelas (PTK) (Suharsimi, 2009). 


\section{JPSP: Jurnal Penelitian Sains dan Pendidikan}

https://e-journal.iain-palangkaraya.ac.id/index.php/mipa/

Subyek penelitian adalah siswa kelas VIII D MTsN 9 Ngawi berjumlah 33 orang siswa yang terdiri dari 17 siswa laki-laki dan 16 siswa perempuan. Penelitian Tindakan Kelas ini dilaksanakan dalam dua siklus yaitu siklus I dan siklus II. Penelitian ini terdiri atas dua siklus, setiap siklus dalam penelitian ini terdiri dari 4 tahap yang meliputi, perencanaan, pelaksanaan tindakan, observasi, dan refleksi. Pelaksanaan penelitian yaitu terdiri dari pelaksanakan pembelajaran sesuai dengan RPP, melaksanakan tindakan perbaikan atas kekurangan-kekurangan yang ada pada siklus sebelumnya, melakukan pengamatan/observasi terhadap pengelolaan pembelajaran di kelas dan melakukan evaluasi belajar siswa pada akhir siklus dan penilaian.

Aktivitas siswa yang diamati oleh observer yang merupakan sejawat peneliti sebagai guru IPA. Lembar observasi yang berbentuk checklist $(\sqrt{ })$ digunakan untuk mengetahui data keaktifan belajar siswa. Data yang dikumpulkan berupa keaktifan siswa dalam pembelajaran dan keberanian dalam menjawab pertanyaan. Tes yang digunakan adalah tes obyektif yang diberikan pada siswa sebanyak 20 soal dengan skor maksimal 100 serta tiap butir soal bobot nilainya 5. Persentase kektifan siswa dapat dihitung dengan rumus sebagai berikut:

Persentase Keaktifan Belajar =

$$
\frac{\sum \text { Siswa yang aktif }}{\sum \text { siswa keseluruhan }} \times 100 \%
$$

Indikator keberhasilan keaktifan belajar siswa klasikal jika 75\% siswa dinyatakan dalam kategori aktif dalam pembelajaran. Data siswa yang diperoleh melalui tes tulis dianalisis dengan rumus:

Nilai $=\frac{\sum \text { Skor yang diperoleh siswa }}{\sum \text { Skor maksimal }} \times 100$

Indikator ketuntasan individu siswa dikatakan tuntas apabila mencapai nilai KKM yang telah ditentukan yaitu $\geq 75$.

Persentase ketuntasan belajar secara klasikal dapat dihitung dengan rumus:

Persentase siswa yang tuntas = $\frac{\sum \text { siswa yang tuntas }}{\sum \text { siswa keseluruhan }} \times 100 \%$

Indikator proses belajar secara dinyatakan berhasil jika $75 \%$ dari seluruh siswa mendapat nilai $\geq 75$

\section{HASIL PENELITIAN}

Hasil pengamatan akivitas siswa diketahui bahwa pada siklus I, persentase siswa aktif yaitu 60,61\% dan siswa kurang aktif yaitu 39,39\%. Pada siklus II, terjadi kenaikan persentase aktifitas siswa yaitu persentase siswa aktif yaitu $81,82 \%$ dan siswa kurang aktif yaitu $18,18 \%$. Bedasarkan data hasil penelitian pada Gambar 1, diketahui bahwa siswa yang tuntas dalam belajar berjumlah 27 siswa $(81,82 \%)$, sedangkan siswa yang tidak tuntas belajar berjumlah 6 siswa $(18,18 \%)$. Sedangkan rata-rata nilai siswa adalah sebesar 77,73. Hasil yang dicapai siswa tersebut dapat dikatakan bagus atau berhasil karena rata-rata nilai siswa telah mencapai kriteria ketuntasan minimal yang sudah ditetapkan sebesar 75. Berdasarkan hasil persentase ketuntasan belajar sebesar $81,82 \%$ juga telah dapat dikatakan berhasil mencapai indikator keberhasilan sebesar $75 \%$. 


\section{JPSP: Jurnal Penelitian Sains dan Pendidikan}

https://e-journal.iain-palangkaraya.ac.id/index.php/mipa/

Perbaikan ini dapat dikatakan berhasil karena persentase ketuntasan belajar siswa telah mencapai $75 \%$ atau lebih serta rata-rata nilai siswa telah mencapai KKM 75 atau lebih.

Tabel 1. Persentase kenaikan aktivitas siswa

\begin{tabular}{lrr}
\hline Siswa & \multicolumn{1}{c}{ Siklus I } & \multicolumn{1}{c}{ Siklus II } \\
\hline Aktif & $60,61 \%$ & $81,82 \%$ \\
Kurang Aktif & $39,39 \%$ & $18,18 \%$ \\
\hline
\end{tabular}

Dengan hasil yang dicapai pada siklus II ini dapat dikatakan upaya pelaksanaan perbaikan pembelajaran IPA Terpadu dengan model pemebelajaran kooperatif tipe struktural think pair share telah dapat dikatakan berhasil atau dapat dihentikan karena telah mencapai hasil indicator yang telah ditetapkan.P enerapan model pemebelajaran kooperatif tipe struktural think pair sharedapat meningkatkan minat dan motivasi siswa. Hal ini terlihat adanya peningkatan aktivitas siswa. Peningkatan keaktifan siswa ini terlihat dari siklus I sebesar $60,61 \%$ atau sebanyak 20 orang siswa menjadi sebanyak $81,82 \%$ atau 27 orang siswa pada siklus II. Penggunaan model pemebelajaran kooperatif tipe struktural think pair share membuat siswa lebih tertarik dalam belajar sehingga memacu motivasi serta minat mereka dalam mempelajari IPA Terpadu dalam materi pembentukan bayangan benda pada lensa cembung.

Berdasarkan hasil tersebut di atas maka penulis menghentikan tindakan perbaikan pembelajaran karena telah dapat dikatakan berhasil dengan tercapainya target indikator keberhasilan yang telah ditetapkan.

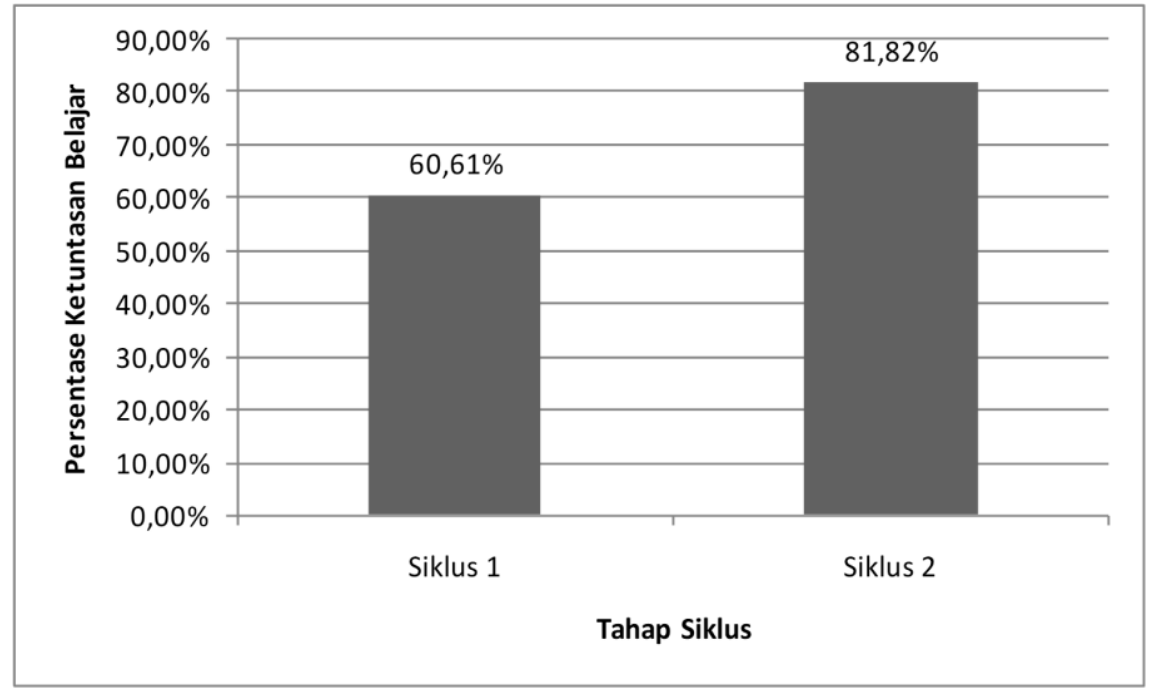

.Gambar 1. Peningkatan jumlah siswa yang memperoleh nilai tuntas pada siklus I dan II.

\section{PEMBAHASAN}

Penerapan model pemebelajaran kooperatif tipe struktural think pair share juga mempengaruhi peningkatan pemahaman dan hasil belajar para siswa kelas VIII D MTsN 9
Ngawi. Hal ini terlihat dari hasil nilai rata-rata kelas pada pelajaran IPA Terpadu pada materi pembentukan bayangan benda pada lensa cembung. Adapun peningkatan nilai rata-rata kelas ini dari siklus I sebesar 71,52 menjadi 


\section{JPSP: Jurnal Penelitian Sains dan Pendidikan}

https://e-journal.iain-palangkaraya.ac.id/index.php/mipa/

77,73 pada siklus II. Kenaikan ini merupakan dampak dari ketertarikan siswa terhadap proses pembelajaran yang disampaikan peneliti melalui model pemebelajaran kooperatif tipe struktural think pair share yang membuat siswa lebih menyukai belajar IPA Terpadu pada materi pembentukan bayangan benda pada lensa cembung. Hal ini sesuai dengan penelitian Mufidah (2013) bahwa pembelajaran kooperatif tipe struktural think pair share yaitu keterlibatan langsung (keaktifan) pebelajar (siswa) dalam mendapatkan pengalaman-pengalaman belajar sangat berpengaruh terhadap hasil belajar dan perubahan tingkah lakunya.

Target ketuntasan belajar siswa akhirnya dapat dicapai pada siklus II. Adapun target ketuntasan belajar yang dimaksud adalah sebanyak $75 \%$ dari siswa minimal mendapat nilai 75. Pada awalnya ketuntasan belajar pada siklus I mencapai $60,61 \%$ atau hanya 20 orang siswa selanjutnya setelah diadakan refleksi dan perbaikan dari kekurangankeurangan pada siklus I, hasilnya sanagt baik pada siklus II. Pada siklus II ketuntasan belajar siswa dapat mencapai $81,82 \%$ atau sebanyak 27 orang siswa. Berdasarkan hasil capaian keberhasilan diatas dapat dikatakan model pemebelajaran kooperatif tipe struktural think pair share telah dapat meningkatkan motivasi belajar siswa sehingga siswa lebih giat dalam mendalami materi pelajaran IPA Terpadu pembentukan bayangan benda pada lensa cembung baik secara individu maupun kelompok.
Hal ini sesuai dengan tujuan atau kelebihan yang dimiliki model pemebelajaran kooperatif tipe struktural think pair share yaitu dalam metode ini dapat mengembangkan kemampuan siswa untuk: (1) lebih akrab dengan temannya sehingga memudahkan untuk berdiskusi dan bertukar pendapat. (2) menciptakan interaksi yang saling asah, asih, dan asuh sehingga tercipta masyarakat belajar, siswa tidak hanya belajar dari guru, tetapi juga sesama siswa. (3) menekankan pada aktifitas belajar siswa sehingga mengajak siswa untuk lebih aktif dan kreatif (SAndayani dkk., 2014; Surraya dkk., 2014).

\section{SIMPULAN}

Berdasarkan data penelitian yang telah diperoleh maka dapat diambil simpulan bahwa peningkatkan hasil belajar siswa Kelas VIII D MTsN 9 Ngawi pada mata Pelajaran IPA Terpadu dalam materi pembentukan bayangan benda pada lensa cembung setelah diterapkan model pembelajaran kooperatif metode struktural think pair share terlihat pada kenaikan persentase ketuntasan belajar siswa dari siklus I sebesar $60,61 \%$ (20 siswa) menjadi meningkat pada siklus II menjasi sebesar 81,82\% (27 siswa) dari keseluruhan siswa sebanyak 33 orang. Peningkatan prestasi belajar siswa juga terlihat pada nilai rata-rata hasil belajar siswa dari sebesar 71,52 pada siklus I meningkat menjadi 77,73 pada siklus II

\section{DAFTAR PUSTAKA}

Andayani S, Lumowa SVT, Boleng DT. 2016.

Pengaruh Model Pembelajaran Kooperatif 
Tipe Think Pair Share Dan Talking Stick Terhadap Motivasi Dan Hasil Belajar Kognitif Ipa Biologi Siswa Kelas VII SMP. Jurnal Pendidikan: Teori, Penelitian, \& Pengembangan, 1(11): 2200 -2204.

Budiati A. 2018. Efektivitas Pembelajaran Kooperatif Tipe Think Pair Share untuk Meningkatkan Hasil Belajar IPA di MTs N Gondowulung. Jurnal Pendidikan Madrasah, 3(1): 65-76.

Fariska C. 2013. Penerapan Model Pembelajaran Kooperatif Tipe Think Pair Share disertai LKS Dalam Pembelajaran Fisika di SMA. Jurnal Pendidikan Fisika, 2(2): 45-53.

Irwansyah M, Mahardika IK, Supriadi B. 2016. Penerapan Model Pembelajaran Kooperatif Tipe Think Pair Share (TPS) Disertai Metode Praktikum Untuk Meningkatkan Aktivitas Dan Hasil Belajar Fisika Siswa Kelas XI IPA 3 MAN 1 Jember. Jurnal Pembelajaran Fisika, 4(4): $372-376$.

Kurniasih D. 2018. Peningkatan minat dan hasil belajar IPA melalui model pembelajaran think pair share. Natural: Jurnal Ilmiah Pendidikan IPA, 5(1): 7-11.I

Mufidah L. 2013. Penerapan Model Pembelajaran Kooperatif Tipe TPS untuk Meningkatkan Aktivitas Belajar Siswapada Bahasan Matriks. Jurnal Pendidikan Matematika, 1(1): 117-125.

Suharsimi. 2009. Penelitian Tindakan Kelas, Jakarta: Bumi Akasara

Surraya L, Subagia IW, Tika IN. 2014. Pengaruh Model Pembelajaran Think Pair
Share Terhadap Hasil Belajar Ipa Ditinjau Dari Keterampilan Berpikir Kritis Siswa. Jurnal Pendidikan dan Pembelajaran IPA Indonesia, 4(1): 1-11.

Trianto. 2013. Model Pembelajaran Terpadu Konsep, Strategi dan Implementasinya dalam Kurikulum Tingkat Satuan pendidikan. Jakarta: Kencana

Yuwono S. 2016. Meningkatkan Minat dan Hasil Belajar Siswa Melalui Penggunaan Metode Kerja Kelompok Di SD kalilembu Tahun Pelajaran 2015/2016. Jurnal Penelitian Bahasa Indonesia, 2(11): 34-35. 